Hansen, Dirk Uwe (Ed.). (2011-2016). Anthologia Graeca (Bände I-III; Übersetzt und erläutert von Jens Gerlach, Dirk Uwe Hansen, Christoph Kugelmeier, Peter von Möllendorff und Kyriakos Savvidis; Bibliothek der griechischen Literatur, herausgegeben von Peter Wirth und Wolfram Kinzig, 72, 76, 79; pp. 195, 456, 322). Stuttgart: Anton Hiersemann, ISBN 978-3-7772-1131-2.

\title{
Juraj Franek
}

Any attempt at a modern translation of Anthologia Graeca, a massive collection of several thousand poems by hundreds of different authors, spanning centuries in time, countless miles in space, and ranging thematically from pious Christian epigrams of its first book to explicit adolescent homosexuality of its twelfth book, is undoubtedly a daunting task, yet this is precisely what the team under the editorial lead of Dirk Hansen set out to do for German-speaking readership under the auspices of Hiersemann's Bibliothek der griechischen Literatur series. Three volumes have been published so far, covering two thirds of the entirety of the Anthologia (Volume I covers books I to V, Volume II books VI to VIII, and Volume III books IX to X). The team behind the translations consists of Kyriakos Savvidis (books I \& VIII), Christoph Kugelmeier (book II), Peter von Möllendorff (books III \& VII), Jens Gerlach (books IV \& X; sections of books VI \& IX) and Dirk Hansen (book V; sections of books VI \& IX).

The first volume opens with a concise yet informative introduction, focusing on the origin, development and function of the ancient epigrammatic tradition, as well as on the transmission history of the collection itself. ${ }^{1}$ The rest of the volumes is dedicated to the German translation and follows a unified format: Each book of the Anthologia is very briefly introduced by the translator (length of these introductions ranges from one single paragraph for Book I to several pages for Book VII), followed by the German

1 Hansen et al. (2011: pp. vii-xxii). translation complemented with page-by-page notes, in general sparse and aimed at general readership, clarifying the who-is-who of ancient Greek mythology and the where-is-what of ancient Mediterranean topology and geography. Some notes go out of their way to explain difficult features of the less easily translatable poems (see e.g. VII, 705), yet for more substantial commentary one should consult Beckby or Gow \& Page (the latter containing only Hellenistic epigrams). ${ }^{2}$ All volumes by Hansen et al. further contain helpful indices of authors, names and objects.

Since Anthologia Graeca has been translated into German in its entirety no less than twice during the second half of the twentieth century - see Hermann Beckby's 1958 bilingual edition in the Tusculum series and Dietrich Ebener's 1981 translation in the Bibliothek der Antike series ,$-^{3}$ I find it instructive to highlight the achievements of the new translation by Hansen et al. by means of comparison with the fruits of the work of their predecessors. By far the most important and to a certain degree potentially polarizing decision taken by the team behind the new volumes is surely the abandonment of the original metre (almost exclusively elegiac couplet) in favour of a free verse, marking a significant departure from both Beckby and Ebener, who keep in with the metrical structure of the Greek text. While there is a handful of exceptions to this rule, as evidenced by poems in the iambic

2 Beckby (1958); Gow \& Page (1965).

3 Ebener (1981). 
trimetre (e.g. VI, 90; VI, 92; VI, 101), the clear majority of the poems in the new German translation relies on tempo, careful choice of words, occasional alliteration and other stylistic devices to convey the "magic" of poetry.

The result is a stunning success - the unshackling of the words from their metrical yoke brings forth eminently clear and readable translations that are as close in spirit as possible with the originals. Similarly liberal approach to the translation of the ancient epigrams has been advocated by the late Daryl Hine in the preface to his Puerilities (English translation of the Book XII of the Anthologia Graeca), arguing that "the effect [of the English elegiac couplet, after replacing longum with an ictus], much-repeated, is rather sedative than, as an epigram should be, piquant, surprising and evocative, in its basic sense of a wake-up call", with a suggestion to "more or less abandon it altogether in favor of a more familiar native meter". "While Hine eventually used rhymed couplet (or even a limerick on occasion!) and Hansen et al. opted for a free verse, both achieve vibrant renditions of the Greek material only made possible by abandoning the lure of the original metre.

Truthfulness to the spirit of the Greek text is further realized by other means as well. In comparison with Beckby in particular, the new team does not shy from translating the more explicit contents of the erotic epigrams adequately. By means of an example, let us con-

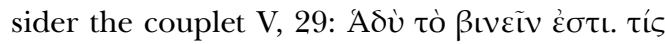

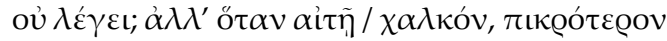

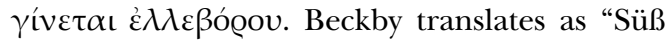
ist's, Liebe genießen. Das leugnet niemand. Doch wenn man / Geld für die Liebe verlangt, wird sie wie Nieswurz so herb.", ${ }^{5}$ while Hansen chose the following rendition: "Süß ist das Ficken, wer würde das leugnen, aber wenn man /
Geld dafür zahlen muss, wird es bitterer als Elleboros." Since the verb $\beta$ เveiv carries an expressive force similar to English "to screw" or "to fuck", one does not have to go to great lengths to demonstrate which translation remains more truthful to the original.

Another feature of the new translation is the occasional conservation of the dialectal features. For instance, the Doric form of the name

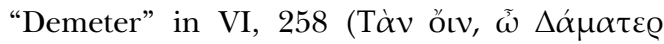
$\varepsilon \dot{\pi} \gamma_{\mu t \varepsilon \ldots)}$ is conserved by Hansen et al. ("Das Schaf, o Damater, du Herrin der Ackerfurche..."), but normalized by both Beckby ("Göttin der Furchen, Demeter, dies Schaf...") and Ebener ("Göttin des Pfluges, Demeter, das Schaf hier..."). ${ }^{7}$ An interesting choice is the indication of textual corruptions via cruces philologorum in the new German translation (see e.g. VI, 288 \& VI, 299), a feature rarely seen in other translations (of the Anthology and otherwise), yet a powerful means to alert the reader that the text he or she are enjoying enjoyed a rather complicated textual tradition.

In conclusion, the new German translation of the Anthologia Graeca by Hansen et al. is a much-welcomed modern rendering of a vast Greek epigrammatic tradition, heartily recommended to all interested in Greek culture and literature. The quality of the three volumes produced so far justifies high expectations for the remaining volumes to come.

Beckby, H. (Ed. \& transl.). (1958). Anthologia Graeca (Vol. I-IV; 2. ed.). München: Ernst Heimeran.

Ebener, D. (Ed. \& transl.). (1981). Die griechische Anthologie in drei Bänden. Berlin - Weimar: Aufbau-Verlag.

Gow, A. S. F., \& Page, D. L. (Eds.). (1965). The Greek Anthology: Hellenistic Epigrams. Cambridge: Cambridge University Press.

6 Beckby (1958: I, p. 601).

7 Ebener (1981: I, p. 235). 
Hansen, D. U. (Ed.). (2011-2016). Anthologia Graeca Hine, D. (Transl.). (2001). Puerilities: Erotic Epigrams (Vol. I-III; transl. D. U. Hansen et al.). Stuttgart: Anton Hiersemann. of the Greek Anthology. Princeton - Oxford: Oxford University Press.

Mgr. Juraj Franek, Ph.D. / j.franek@mail.muni.cz

Department of Classical Studies

Masaryk University, Faculty of Arts

Arna Nováka 1, 60200 Brno, Czech Republic 